\title{
Kammerherre Rosens Optegnelser fra Flensborg 1864.
}

De efterfølgende Dagbozsoptegnelser af den danske Overpræsident i Flensborg Kammerherre Rosen (f. 1819 i Segeberg, død 7. Decbr. 1891) er stillede til Tidsskriftets Raadighed af hans Hustru, hrem ogsaa Orersættelsen af den tyske Original skyldes.

1. Januar. Kongen kommer Kl. 12 fra Kjøbenhavn; jeg ledsager ham til Slesvig.

2. Januar. Middag hos Stemann's med Scheele og Bagger ${ }^{1}$ ). Krogh i Süderstapel ${ }^{2}$ ) skal være Minister. 3. Januar. Stemann taler om, at han selv muligvis skal være Minister.

5. Januar. Med Kongen til Frederikstad.

7. Januar. Kongen kommer fra Slesvig; jeg henter ham; han reiser til Sønderborg.

10. Januar. Kammerherre Johannsen ${ }^{8}$ ) reiser til Kjøbenhavn for at blive Minister.

1) Henholdsvis Præsident, d. 1876, og Raad i den slesvigske Appellationsret i Flensborg.

2) 1851-64 Landfoged i Stapelholm, d. 1891.

3) Amtmand over Husum og Bredsted Amter. Minister for Slesvig i Monrads og Bluhmes Ministerier, d. 1888. 
22. Januar. Selskab hos os.

24. Januar. Pastor Carstens introduceres ${ }^{1}$ ).

30. Januar. Selskab hos os paa vor Bryllupsdag.

31. Januar. Om Middagen Telegram fra General de Meza, at Jernbanen ikke mere skal gaa til Rendsborg. Kort før Togets Afgangstid forhindrer jeg Afgangen. Jeg lader Toget gaa til Klosterkro, da der er mange Officerer med og mange fra Frederiksstad. Om Aftenen Kl. 8 kommer Staffet med Skrivelse fra Overkommandoen, at Krigen begynder imorgen. - Bestemmelser angaaende Jernbanen.

1. Februar. Kongen kommer Kl. 12 tilligemed Monrad pr. Dampskib. - Jeg giver ham straks Underretning om Tilstanden og viser ham Overkommandoens. Skrivelse. Meget frapperet over, at Krigen begynder. - Kongen vil strax til Slesvig. Jeg bestiller pr. Telegraf Vogne til Dannevirke, og vi tage afsted med Jernbanen. - Jeg taler meget med Kongen i Vognen. Han roser Monrad meget!! Ved Dannevirke staa vi ud, og maa gaa et langt Stykke til Vognene. - Jeg tager med til Slesvig - besøger Sigismund ${ }^{2}$ ) og har en Samtale med ham og Kauffmann ${ }^{3}$ ) paa Generalkommandoen. - Aftale angaaende Togenes Afgang indtil Dannevirke bliver truffet. Vi blive enige om, at Tognene skal vedblive at gaa til Frederikstad. Derpaa tager jeg. tilligemed Kongens fleste Ledsagere pr. Jernbane til-

1) Efter Krigen bekendt som Præst ved den danske Kirke i Flensborg, død 28. Januar 1903.

2) Overpræsidentens Broder, Major og Souschef ved Over. kommandoen, faldt d. 18. April.

3) Oberst og Stabschef ved Overkommandoen. 
bage til Flensborg. Kun Monrad og Dahl ${ }^{1}$ ) blive hos Kongen i Slesvig. Vi spise sammen hos Rasch. Alle ere fulde af Bekymring og meget trykkede.

6. Februar. Tilbagetog fra Dannevirke! Overkommandoen i Huset hos os.

7. Februar. Kl. 1 om Natten rider Overkommandoen bort - der bliver blæst Allarm, og de sidste af vore Tropper trække ud af Byen nordpaa. Jeg siger Farvel til min Broder Sigismund paa Gaden. Huset bliver gjort reent. Indtil Kl. 7 ligger jeg paa Sophaon. Ua rider de første preussiske Husar- og Ulan-Patruiller gjennem Gaden med Pistoler i Haanden!

Kl. 8 melder der sig 5 Skippere, som erklære, at de ligge her med Magazin-Forvaltningens Ladninger. De sperge, hvad de skal gjøre. Jeg svarer: Seile til Sønderborg og henvende sig til Magazin-Forvaltningen. De sige: det kan de ikke, Vind og Is forhindre dem.

Der melder sig en Tjenestepige fra Musikus Demuth og erklærer, at hun har Proviant, som tilhorer den danske Armée, i sit Kjøkken og spørger, hvad hun skal gjøre dermed? Jeg sender Greve (Retstjener) derhen, lader det aflaasede Kjøkken aabne, optage Fortegnelse, og beordrer, at Alt foreløbig skal blive liggende.

Kl. 81/8. Jeg gaar til Indkvarteringsbureauet og giver Kommissionen (tilstede ere Balle, Petersen, Hansen og 2 Skrivere) Ordre til at gjøre en Streg $i$ alle Bøger og Protokoller og skrive derefter: „Kaiserlich Kongen.

1) Oberstløjtnant og fungerende Generaladjudant hos 
Oesterreichische und Königlich preussische Truppen“, og derpaa at fortsætte med Indkvarteringen aldeles paa samme Maade som hidtil; en preussisk HusarUnderofficeer er tilstede.

Derfra gaar jeg til Borgerforeningens Lazaret, besoger Bluhme 1), gaar igjennem den store Sal og taler med flere Saarede. Jeg møder Lazaretforvalter Rasmussen og siger til ham, at han skulde sige til de fremmede Troppe-Kommandører, at Lazaretterne forelobig staa under mig.

Paa Gaden ser jeg kun enkelte slesvig-holstenske Flag, de nordligste fra mig hos Funcke, Callsen og Marr (Raadhusgade).

Kl. 9. Kirkefoged Iwersen kommer og melder, at der var bleven forlangt af ham, at han skulde heise det slesvig-holstenske Flag paa Nicolaikirken - hrad han skulde gjøre? Jeg svarer: han skulde erklære, at han skulde have Ordre dertil fra Patronatet og fra mig.

$9^{8 / 4}$. Preussiske Kyrasserer trække igjennem Gaden. En Flok Drenge med et slesvig-holstensk Flag trække gjennem Gaden og synge "Schleswig-Holstein".

10. Der viser sig alle Slags fremmede Skikkelser paa Gaden. Stoehr kommer til mig og taler om Nødvendigheden af at heise et slesvig-holstensk Flag - hvilket jeg afviser. Han siger, at mange Folk fra Landet ville komme til Byen.

101/2. Jeg sender ved Greve mit Kort til den nuværende Høistkommanderende Ritmester von Weissen

3. Marts.

1) Sekondløjtnt. i 3. Inft.-Reg., saaret ved Mysunde, død 
og lader ham sige, at jeg her er den øverste Embedsmand, og lader ham bede, hris han forlanger Noget af Byen, da at henvende sig til mig.

Kl. 11 melder sig Ritmester von Weissen med cirka 60 danske Fanger og nogle danske Heste. De blive anbragte i Tugt- og Arbeidshuset, og der bliver rekvireret Forpleining for dem af Indkvarteringskommissionen.

113/4. Trækker General Wrangel og 1 Cavalleriog 1 Infanteri-Afdeling her igjennem.

$12^{1 / 4}$ melder Kirkefoged Bladt, at 4 Borgere havde forlangt af ham, at han skulde heise det slesvigholstenske Flag paa Kirken. Da han havde nægtet det, havde de erklæret, saa vilde de gjøre det selv. $\mathrm{Nu}$ var de beskjæftigede dermed.

Kl. 1. Wrangel sender en Adjudant med den Befaling til mig strax at møde hos ham. Jeg klæder mig paa i Civil med Ordner og kjører til ham i min Kareth til Wilhelm Schmidt's Hus. - Bliver strax indladt. Wrangel overfuser mig meget barsk: "Hvorfor er De ikke af dem selv kommet til mig? Jeg er vant til, at Embedsmændene melde sig hos mig!" Jeg svarer ham, at jeg havde ment, at maatte oppebi hans Befaling, hvilket jeg syntes stemmende med mit Forhold som Kongen af Danmarks Embedsmand. Wrangel peger paa mine Ordener og siger: „Naa ja, jeg ser, at Deres Konge har hædret dem, og jeg vil sige Dem, at jeg respekterer de Embedsmænd, som forblive tro imod deres Konge. Hrad hedder De"? Da jeg nærnede ham mit Navn, bemærkede han, at vor Familie vel stammede fra Sverige - derfra stammede 
han ogsaa. Han blev nu venlig og forekommende, og sagde til mig, at han naturligvis maatte forlange ubetinget Underkastelse, ogsaa at jeg skulde gjøre for Arméen, hvad der blev forlangt - endvidere, at jeg undlod enhver Forbindelse med den danske Armé. Jeg skulde levere ham en Fortegnelse over al tilbageladt dansk Eiendom, og det til i Aften, hvorpaa jeg svarede, at dette var umuligt, da vor Armé forst havde forladt os i Nat, men til imorgen Aften skulde jeg skaffe Fortegnelsen; dette gik han ind paa. Derpaa sagde han til mig, at han ikke vilde taale de oprorske Demonstrationer og navnlig forbyde alle augustenborgske Demonstrationer. Alle Flag vilde han forbyde og bød mig at udføre dette Forbud; naar jeg behøvede Soldater, kunde jegr rekvirere dem. Kun det preussiske og asterrigske Flag ligesom ogsaa det slesrigske Flag vilde han tillade. Jeg takkede ham og sagde, at heri var jeg enig. Derpaa maatte jeg give ham Haanden paa ikke at foretage noget Fjendtligt imod Arméen - jeg lovede ham at adlyde hans Befalinger eller udtrykkelig, aabent og personlig at erklære ham, hvis jeg fandt ikke at kunne forene det med Pligterne imod min Konge. Derpaa sagde Wrangel, at vi nok vilde komme ud af det med hinanden - naar jeg onskede Noget eller kom i Forlegenhed, skulde jeg kun henvende mig til ham; han vilde give Ordre til, at jeg til enhver Tid skulde indlades til ham. Wrangel sagde saa til mig, at han stadfæstede mig og alle ovrige Embedsmænd i deres Embeder, - vore Indtægter skulde blive ubeskaarne, det kunde jeg sige dem Alle. Byens Kasse og alle andre under mig staaende Kasser skulde blive 
urørte - aldeles som hidtil. Derpaa afskedigede han mig naadigt, efter at han til Slutning gav mig det Hverv at sende Politimesteren, som han medgav en Officer og Soldater, til Søndertory for at jage en Folkeforsamling fra hinanden, som, medens vi talte sammen, med megen Larm var trukket gjennem Gaden for at proklamere Augustenborgeren.

Kl. 2. Derpaa gik jeg til Raadhuset.

Senere ankommen til Wrangel tilligemed Vogel v. Falkenstein ${ }^{1}$ ), gik Falkenstein først alene ind i Værelset, hvorpaa der blev kaldt paa mig. Wrangel spurgte mig: Hvad har jeg sagt Dem angaaende Flagene? Jeg svarede: "At alle Flag vare forbudte med Undtagelse af de preussiske, osterrigske og slesvigske." Han vender sig til Falkenstein og siger: "Det er rigtigt, det har jeg sagt!“ "Hvad er . da det slesvigske Flag?" spørger Falkenstein. „Blaat og gult", svarer jeg. "Det ses jo ingen Steder", siger han. "Nei", svarer jeg, "siden de slesvig-holstenske Agitationer og Augustenborgernes Revolutions-Bestræbelser have begyndt, har dette Parti lavet sig et Flag, sammensat af det holstenske Flag rødt og hvidt og det slesvigske blaat og gult, hvilket i Begyndelsen havde disse 4 Farver, men senere, som alle Oprørsflag, blev omdannet til et trefarvet med Udeladelse af den gule Farve. Deraf er det saakaldte slesvig-holstenske Flag opstaaet, som idag er heist her af Augustenborgerne og Demokraterne. De to Generaler se paa hinanden, og Falkenstein siger: „Det kan Altsammen nok være saa-

1) Stabschef ved den allierede preussiske og østrigske Hær. 
dan, men $n u$ er det Flag, som De har ladet nedtage fra Raadhuset, det slesvigske, og det har Feldmarschallen tilladt, altsaa har De ikke havt Lov til at lade det tage ned." Hele denne Samtale blev ført meget hurtig og heftig, hvorpaa Feldmarschallen slog mig paa Skulderen og sagde til Falkenstein: „Herr von Rosen har handlet efter bedste Overbevisning, vi have ikke forstaaet hinanden; Herr v. Rosen har gjort sin Pligt." Derpaa sagde Falkenstein, at han ikke havde vidst, med hrem han havde talt paa Raadhuset - han var bleven heftig, fordi han havde formodet forsætlig Modstand imod Overkommandoens Befalinger, og jeg maatte ikke glemme, at det $\mathrm{i}$ Krigen ikke altid gik, som det skulde. Derpaa bukkede han for mig (dette skulde være en Undskyldning). Saa sagde Wrangel: "Nu altsaa ved De, at jeg kalder dette Flag det slesvigske, som jeg tillader.“ Jeg bukkede og sagde: „Deres Excellence maa tilgive, at jeg for at undgaa senere Misforstaaelser maa udbede mig en bestemt Instruktion om, hvorledes det Flag ser ud, som Deres Excellence tillader." Wrangel gik til Vinduet, tog mig red Haanden, aabnede Vinduet og saa sig om; endelig fandt hans Øie et slesvig-holstensk Flag, henad Søndertorv til, og han sagde: „Ser De det Flag — det tillader jeg - det er det slesvigske Flag, forstaar De mig ?" „Ja, Deres Excellence“, sagde jeg. „Godt“, sagde han, „paa Gjensyn imorgen!“ Og jeg gik atter til Raadhuset.

8. Februar. Jeg bringer Wrangel Fortegnelserne over kongelig dansk Eiendom. Han er meget venlig, takker - skænker alt Brød til de Fattige. Han sagde til mig, at han vilde sørge for de Saarede i Lazaret- 
terne, som han havde besøgt; jeg skulde sørge for, at de fik Alt saa godt som muligt; han vilde betale Alt. „De skal behandles som mine Børn, forstaar De? Skriv det til Deres Konge, jeg tillader Dem i det Hele at skrive til Deres Konge, hvorledes det staar til her."

9. Februar. Jeg gaaer til Kommissær v. Zedlitz ${ }^{1}$ ). Han er meget hoflig. Jeg meddelte ham, at jeg var bleven her paa min Konges Befaling, men vilde, saalænge jeg var her, naturligvis underkaste mig Magten. Naar jeg ikke længere kunde det, vilde jeg meddele det. Han svarede, at det var et Standpunkt, hvormed han var fuldstændig enig. Han selv var mig maaske bekjendt fra hans forrige Stilling i Berlin - derefter vilde jeg kunne bedømme ham; alle Oprørsbestræbelser og politiske Demonstrationer, navnlig alle augustenborgske, vilde han undertrykke og være mig behjælpelig dermed. De herværende Forhold vilde han studere og nøie tage Hensyn til. Efter hans hidtilværende Erfaring existerede her i Landet tre Partier - det tyskdemokratiske, det slesvigholstensk-augustenborgske og det danske, d. $\nabla$. s. det, som trofast er hengiven til sin Konge. At han kun kunde respektere det sidste, fremgik af hans Fortid (!!) Jmorgen vilde kan komme til mig, saa kunde vi tale videre.

Han er ikke kommen, og vi have ikke talt videre ? 10. Februar. Middag hos Wrangel. Stort Selskab; den hele Stab - Storhertugen af Mecklenborg - Gablenz og Gondrecourt. Jeg bliver placeret imellem Ge-

1) Prøjsisk Civilkommissær, der i Forening med den nfnævnte Revertera overtog Hertugdommernes Styrelse. Indtil da Politipræsident i Berlin. 
neraladjudant? og Adjudant Grev Eulenburg, der var vel 50 Personer tilbords. Samtale med Naboerne om intetsigende Ting. Østerrigerne og siden Storhertugen af Mecklenborg, som først senere kom tilbords, fortælle om Fægtningen i Sundeved, Storhertugens. forste Vaabendaad. Wrangel forestiller mig tvers over Bordet for Storhertugen: „En Mand som er sin Konge tro hengiven, en Hædersmand "“ Storhertugen takker mig, som paa hans Anbefaling har skaffet en mecklenborgsk Bagersvend Optagelse som Borger her. En pinlig Historie den hele Middag $\rightarrow$ dog slap jeg godt derfra.

13. Februar. Kl. 10 bliver jeg kaldt til Zedlitz; forefinder Hammerich der. Foruden ham en preussisk Politiofficer Langer og Advokat Kraus fra Kiel, Sekretær hos Zedlitz. Zedlitz forklarer kort, at de forenede Regeringer Østerrig og Preussens Interesser fordre, at Politimester Hammerich bliver afsat fra sit Embede, hvilket indtil videre var overdraget Langer. Kraus skulde i min Nærværelse besørge Overleveringen. Der bliver ingen andre Ord vexlet, kun at Hammerich udbeder sig Befalingen skriftlig, jeg beder ligeledes om skriftlig Meddelelse. Begge Dele lover Zedlitz. Derpaa gaa vi til Hammerichs Bolig. Langer tager Akterne i Besiddelse. Hammerich erklærer efter Regnskabernes Afslutning at ville aflevere sine Kasser til mig, hvormed man er tilfreds.

Om Aftenen lod Wrangel mig hente. Jeg bringer ham General de Meza's Photographi, hvilket han har søgt om i Byen. Han siger: "Den Foræring tager jeg imod. Altsaa det er Deres General! Den Mand 
har reddet den danske Armé. At han trak sig tilbage, var ikke blot klogt, det var viist. Og den Mand vil De nu stille for en Krigsret? Verden er uretfærdig!"

15. Februar. Jeg besøger Grev Revertera, den osterrigske Civilkommissær; finder i ham en elsværdig, elegant Mand, til hvem jeg kort meddeler min Stilling og derpaa taler med som med en Kavalér. Jeg. tilbyder at skaffe ham $0 \mathrm{~g}$ hans Kone Bolig i Oberstlieutnant Nielsens Leilighed, hvilket han modtager med megen Tak. Om Aftenen besøger Hugo Plessen fia Eckernførde os, som er meget vred over, at man hos Zedlitz og Revertera har modtaget ham temmelig koldt og lidet høfligt, og beklager sig over, at man ikke handler, som det er lovet i Proklamationerne.

16. Februar. Grev Revertera lod mig sige, at han ikke behøvede Lejligheden, da han blev boende hos Finecke. Til mig kom han ikke, saaledes som han sagde igaar.

Min Erklæring som Følge af Bekjendtgjørelsen fra den Kongelig preussiske Civilcommissarius for Hertugdømmet Slesvig fra 8. Februar 1864.

Ifølge Bekjendtgjørelsen af Hr. Kgl. prenssisk Civilcommissarius for Hertugdømmet Slesvig, Friherre von Zedlitz, af 8de ds. afgiver jeg herved $i$ min Egenskab af Overpræsident og 1ste Borgmester af Byen Flensborg og i min Egenskab af Commissarius for Jernbanerne i Hertugdømmet Slesvig følgende Erklæring:

At jeg, saalænge Besættelsen af Hertugdømmet Slesvig varer, vil underkaste mig den af Overbefalingen over de forbundne Arméer constituerede øverste Autoritet i Landet, og de Herrer Civilkommissærer. 
Hvortil jeg ærbødigst tillader mig at tilføie, at jeg strax vil tilkjendegive, saasnart jeg mener, ikke længer at kunne forene denne Underkastelse med den af mig afgivne Troskabs- og Embedsed.

\section{F. von Rosen.}

Flensborg, den 15 Februar 1864.

16. Febr. Hammerich vil afreise imorgen tidlig. Han er legemlig meget medtaget, forøvrigt elskværdig og fornuftig. Han reiser over Lübeck til Kjøbenhavn med Kone og 6 Børn. Iaften afleverer han sine Kassebeholdninger til mig.

23. Febr. Sidste Nat er Løvemonumentet ødelagt. - Halen er brækket af, og Løven forrykket paa sin Sokkel. Ifølge Referatet fra Politibetjent Jespersen til mig, var igaar Aftes Kl. 11 en Rebslagersvend kommen til ham paa Gaden og havde sagt, at der var en Masse Mennesker paa Kirkegaarden for at rive Loven ned. Jespersen gik til Vagten og fik 10 Mand med; de gik til Kirkegaarden, 2 Mand udenom paa hver Side. Da de gik ind paa Kirkegaarden, løb mange Mennesker bort - Alle borte - men Værktøjet have de ladet ligge, Stiger, Tove, Dunkraft. Jesporsen skruede Loven ned igjen, som de havde hævet omtrent 6 Tommer, lagde stiger, Tove etc. i en Kasse, som stod der. De to udenfor Kirkegaarden posterede Patruiller have hver fanget to Mand. Sagerne og de fire Fanger. bleve derpaa bragt til Kommandanten og bleve der om Natten. Halen blev forst næste Morgen fundet i Reberbanen. Jespersen har raporteret det Hele til Overpolitibetjenten og denne til Politimesteren. Forhørt er han ikke. De 4 Fanger ere fra Altona (som man 
mener), Værktøiet er Jernbaneværktøi fra Altona. Kommandanten var meget opbragt over den skjændige Daad. Imorges ere de 4 Arrestanter bragt til Politistationen, ogsaa Sagerne. Efter nogle đieblikke har Politimesteren ladet dem løbe. Jespersen har lige mødt en af dem paa Gaden, han truede med, at de snart kom igjen, saa skulde han faa sin Tak. Politimester Langer skal have sagt til Altonaerne: de skulde bare rolig reise hjem - hvad de havde begyndt hemmeligt om Natten, vilde han fuldføre aabenlyst om Dagen.

Senere. Jeg skriver til Langer Kl. 12 om Middagen : "If er i Nat Løvemonumentet paa den herværende Begravelsesplads delvis demoleret, og Løven forrykket paa Sokkelen; en Politiundersøgelse er allerede i denne Anlednning forberedt. Da den snarlige Istandsættelse af Monumentet vil blive foranlediget ved Kirkegaardsinspektionen, ansøger jeg tjenstlig Hr. Politimesteren om at ville meddele mig, om der med Hensyn til den indledede Politiundersøgelse vil være Noget at indrende inıd, at Loven atter bliver sat paa Plads paa Sokkelen og bliver repareret".

Herpaa modtog jeg den 24. ds. følgende Svar :

„Deres Høivelbaarenhed meddeler jeg som Svar paa Deres meget ærede Skrivelse af 23. ds. ærbødigst, at Bortfjernelsen af Løven fra Kirkegaarden allerede er anordnet."

Nedtagelsen af Løven har Jernstøber Dittmann overtaget; "den skal“, siger Langer „bringes i Sikkerlhed !" Derved er intet at gjøre. 
24. Febr. Plättner ${ }^{1}$ ) kommer paa Grund af Begravelser og Ligkister. Han fortæller, at der den 22. ds. har været en større Kamp ved Dybbøl. Mange Saarede, Preussere, ere bragt hertil; ogsaa Officerer. Men desværre ogsaa mange Fanger - omtrent 150. Mange Overløbere derimellem, som frivillig har ladet sig fange; deriblandt flere Flensborgere. Skibsmægler Laban hører dertil; han har strax faaet sin Frihed og har saa $i$ den danske Uniform med hvidt Bind om Armen været i Sangforeningen og har sunget.

Snedker Miüller kommer til mig og meddeler: Igaar Aftes i "Euterpe" er det kommet paa Tale ved Kaptain nu Havnefoged Hansen, at Flïgel havde fortalt, at der hos mig paa Loftet staar den i sin Tid fra St. Pauls ${ }^{2}$ ) Grav borttagne Tavle. Derover havde der været stor Ophidselse. - Tavlen staar ganske rigtig hos mig; jeg har, da jeg flyttede ind i Lassens Lejlighed, fundet den paa Loftet, og den er saa flyttet med herhen; den staar nu her paa Pulterkamret.

25. Febr. Kleving fortæller mig, at Løven skaI til Hamborg. Men foreløbig bliver den bragt til Regjeringsbygningen og gjemt der.

Atter en Begravelse paa Kirkegaarden. Kommandanten begynder at tale om St. Pauls Grav og spørger, hvor Tavlen er, som han har hørt Tale om. Jeg siger, at det rimeligvis er den, som staar hos mig. - Vi ser paa Graven, som er holdt godt istand. Der staar et

1) Den bestemte flenshorgske Patriot, Garver Jakob P. d. 1893.

2) Slesvig-holstensk Officer, falden under Belejringen af Fredericia 1849. 
Kors derpaa med Narn; en Tavle mangler. Da kommer Nicolaisen til og forklarer, at den Tavle havde han for nogle Dage siden taget bort for at reparere den; den har hidtil altid staaet paa Graven; han faar Ordre til atter at sætte den paa Plads.

3. Marts. Lieutnant Bluhme skal amputeres; Consultation imellem den preussiske Overstabslæge, Dr. Silfferberg, Dr. Aaby og Dr. Salomonsen. Kl. 3 besøger jeg Bluhme. Han er fattet og elskværdig. Amputation Kl. 4. Han døer 5/2. - Jeg skriver det til Faderen. Telegram til ham, at hans Datter ikke skal komme, Alt ved Pontoppidan.

Historien med Tavlen paa St. Pauls Grav opklares; Nicolaisen meddeler mig, at den Tavle, han havde hjemme nu, har paa den ene Side en Indskrift, som man 1852(?) ikke vilde taale. Derfor blev denne Indskrift oversmurt med Kit og saa overmalet. Tavlen var derpaa vendt om, og kun Navnet indgraveret paa den anden Side. Saaledes (omvendt) har Tavlen i alle de Aar ligget paa Graven. Den Tavle, som ligger hos mig paa Loftet, er en hel anden. Indskriften paa den er :

\section{Dem Krieger Heil!}

Erkämpft er mit dem Schwerdte Sich nur ein Grab in einer freien Erde.

Den hier ruhenden Opfern des SchleswigHolst: Freiheitskampfes gewidmet von dankbaren deutschen Brïdern. 
4. Marts. Her i Arresten sidde som Krigsfanger Pastor Bülow ${ }^{1}$ ), Inspektør Thaysen fra Sandberg, Herredsfoged Sarauw fra Mogeltonder; de ere, ligesom tidligere Etatsraad Hammerich ${ }^{2}$ ) og Andre, anbragte i den sxdvanlige, nye Arrestbygning bagved Raadhuset. De have siddet i 4 Dage uden at blive forhørt.

6. Marts. Fordi jeg endnu ikke har næont, at Provst Hansen for nogle Dage siden er afskediget som Prorst, og Pastor Peters er bleven konstitueret, vil jeg notere det her. Pastor Peters siger, at han vil gaa sala hensynsfuldt frem som mulig. Efter Omstændighederne finder jeg dette Consistorium ret heldigt. Ogsaa Wedell $^{3}$ ) er tilfreds dermed. - Schleisner er afskediget $^{ \pm}$) Det lader til, at man atter vil lægge Medicinal-Sagerne under Kiel. Ruppel fra Slesvig er beordret at hjælpe til med at ordne denne Sag.

10 Lærere ved den latinske Skole ere afskedigede; derimellem naturligvis Simesen ${ }^{5}$ ).

Den 1ste Marts melder Nielsen, at „Stænderarchivet" er opbrudt. Jeg skriver d. 2.den til den øverste Civilinstans, og til Politimester Langer sendte jeg on Afskrift: „Igaar meldte Brandmajor Nielsen, til hvem Lokalopsynet over Regeringsbygningen er overdraget, at han havde fundet Provincialstænderforsamlingens Archiv opbrudt. Jeg fulgte strax med ham til Stænderhuset $\sigma \mathrm{g}$ fandt, at Doren til Archivværelset var aabnet med Vold. Om der er borttaget Akter af

1) Fra Dybbøl.

2) Borgmester i Haderslev.

3) Wedell-Wedellsborg, Amtmand over Flensborg Amt.

4) Fra 1853 Medicinalinspektør for Hertugdømmet, død 1900.

5) Skolens Rektor, død 1890. 
Archivet, kan jeg ikke bestemt bedømme, fordi Archivet ikke er mig nøiere bekjendt, og jeg overhovedet ikke har set det siden den sidste Stænderforsamling.

Men da den kongelige Kommissær efter enhver St:enderforsamligs Slutning ifolge Befaling af Ministeren for Hertugdømmet Slesvig har overleveret mig Archivnøglerne til Opbevaring og Aflevering til den næste Kommissær, og jeg altsaa for saavidt er ansvarlig for Archivet, har jeg atter ladet Doren lukke med en ny Laas og undlader ikke herved ærbødigst at bringe denne Sag til den overste Civilinstans's Kundskab."

Hidindtil er der intet Svar fulgt herpaa.

6. Marts. Igaar kom Kommandanten til mig og sagde, at han havde faaet Ordre fra Feldmarschall Wrangel, at han nøiagtig skulde meddele, hvorledes det hang sammen med Løvemonumentets Reisning. - Nu turde intet røres paa Kirkegaarden eller graves der; han havde opstillet Skildvagter og givet Ordre til at arrestere, og, hvis det blev nødvendigt, skyde Enhver, som rørte Noget dér. Da jeg Kl. 3 kom til Kirkegaarden for at være tilstede ved en Begravelse, arbeidedes der paa Nedtagelsen af Løvens Fundament, sprængte Steen o. s. v.!!! Saadan gaar det!!! Paa Kommandantens Bøn om Efterretninger, har jeg idag skrevet folgende til ham :

Deres Høivelbaarenhed

undlader jeg ikke at meddele, at jeg ikke har noget Væesentligt at tilføje til Referaterne i Flensburger Zeitung, angaaende Festlighederne ved Løvemonumentets Afsløring og den ved denne Leilighed holdte Tale. Hvad angaar Pladsen til Monumentet og dets 
Omgivelse, saa bestod den før Monumentets Reisning dels $i$ en bred Fodsti med to Rækker Popler, dels i Grave (ikke Eiendoms Grave) hvor civile Personer vare begravede, og dels af de faldne Officerers og Soldaters Grave. For at forberede Pladsens Jevning blev der lavet en Fortegnelse af de paa det Sted begravede Civilpersoner af Opsynsmanden ved Kirkegaarden, Munderloh, og Magistraten overdrog nu afdøde Senator Petersen at udvirke Tilladelse hos de Begravedes Slægtninge til enten at jevne Gravstederne (af hvilke forresten kun faa endnu bleve vedligeholdt af Slægtningene) eller at tillade Omflytning af Ligene og Gravstederne til en nærliggende Plads. Senator Petersen har afgjort denne Sag saaledes, at han forst sendte en herværende Borger (Skræddermester Hoe) til de Vedkommende, til hvem de allerfleste erklærede, at de Intet havde at indvende imod den paatænkte Jevning af Gravstederne. Med dem, som ikke vare: enige heri, har Senator Petersen selv forhandlet. Resultatet blev, at 8-10 Lig bleve flyttede, og Gravstederne bleve uforandret istandsat igjen paa det nye Sted, hvorefter den omtalte Plads paa Flensborg Kirkegaard blev stillet til Disposition for Comiteen til Reisningen af Løvemonumentet. Istandsættelsen af Pladsen og Gravhøien som ogsaa Opstillingen af Monumentet or besørget af Comiteen. Til Slutning er der udfærdiget et formelt Aktstykke, af 10. Dec. 1862, hvorved Kirkegaardsinspektionen overdrager Pladsen til Krigsministeriet til vedblivende Besiddelse.

\section{Beretning til Civiløvrigheden over Udgifterne}

ved Jernbanevæsenet.

Igaar var Fru $v$. Bertouch her. Hendes Mand kan ikke forlade Øen (Nordstrand ${ }^{1}$ ), fordi Befolkningen forlanger hans Afskedigelse; da han Intet ved, kommer Konen herhen for at faa Noget at vide her. Hun.

1) Hror han var Herredsfoged. 
er meget fornuftig og reiser tilbage. Bertouch bliver, saalænge han kan.

Grove $^{1}$ ) har været hos Kommissærerne. ThomsenOldenworth $^{2}$ ) har afskediget ham. Grove har protesteret. Kommissærerne sige, at de ville overveie Sagen nærmere, saa skulde han faa Besked; han reiser tilbage til Husum.

8. Marts. Ifølge Civilkommissærernes Ordre bliver i min Nærværelse Regeringsbygningen taget i Besiddelse af Politimester Langer og Centralkasserer Wilhelm, og overgivet Kjøbmand Olfsen-Bagge til Forvaltning. Tømmermester Nielsen er altsaa sat ud af Funktion. Archivet overtage de ogsaa, og jeg maa udlevere Noglerne.

9. Marts. I Jernbaneanliggender komme til mig, legitimeret ved Skrivelse af Civiløvrigheden, Jernbanedirektør Løffler og Premierlieutnant Kallenborn ; legitimeret er endvidere Kaptain i Generalstaben von Bronsart. Meningen dermed er Aabningen af den Nordslesvigske Jernbane. Om Aftenen Forhandling med de To, Dr. Paulsen Mr. Louth ${ }^{3}$ ) og Human hos mig. Resultatet bliver, at Jernbanen skal aabnes til Rødekro, saasnart som mulig.

Min Gage m. m. bliver mig udbetalt.

10. Marts. Kommandanten Major Funck sender mig følgende Telegram til Eftersyn:

1) Ingenigr, fra 1850 Vandbygningsdirekter for Hertugdømmet, død 1871.

2) Leder af den slesvigholstenske Opposition i de slesvigske Stænder, 1864-65 Amtmd. i Husum død 1891.

$\left.{ }^{8}\right)$ Driftsbestyrer for den sydslesvigske Jærnbane ${ }^{\text {. }}$. 
Til Kommandanturen i Flensborg.

Den danske Lieutnant Bluhmes Lig skal udleveres til Slægtningene. Kisten skal indesluttes $i$ en med Zink beslaaet Ligkiste, og befordres til 1ste Corps i Graasten. To fangne danske Underofficerer blive samtidig sat i Fribed som Ledsagere. Fangetransporten ankommer $d .11$ te, Omkostningerne ere at likvidere ved Lazarethforvaltningen.

Feldmarschall v. Wrangel.

Den 12te om Morgenen Kl. 9 skal Liget bringes bort fra Kapellet.

11. Marts. NB. I Skolekassen hos Regnskabsforer Bladt er en Kassebeholdning af rigelig 3300 Rdl,, hvoraf 2000 Rdl. staa i Banken.

Med den fungerende Rektor ved den herværende Skole aftaler jeg, at Caspar Christiansens Hus forelobig skal benyttes til Skole. Med Wilhelm Schmidt aftaler jeg, at Leien bliver 50 Rdl. maanedlig, som skulle betales af Skolekassen.

12. Marts. Ovennæunte Sager (en ikke medtagen Fortegnelse over Løjnant Bluhmes Efterladenskaber) har jeg overleveret Kommandanten for at sende dem til Sønderborg samtidig med Liget. Kl. 9 bliver Liget bragt bort fra Kirkegaarden, fulgt af 2 frigivne Underofficerer, Kommandanten og mig, Pastor Graae og Moltke, Colding, Klewing o. s. v. Kisten er smykket med Krandse. Vi ledsage Liget indtil Chausséen.

13. Marts. Wedell er atskediget. Anledningen er, at Wedell ikke vil constituere en Præst, som har hyldet Prindsen af Augustenborg. Moltke bliver constitueret som Amtmand ${ }^{5}$ ).

5) Herredsfgd. i Vis og Ugle Herreder, gift med Overpræsident R.'s Søster, død 1886 som Amtmd. i Hjørring. 
Knuth meddeler mig, at han, Wilh. Schmidt og Kjøbmand Hansen fra Nørretorv igaar Aftes have været hos Zedlitz for at protestere imod Flensborgernes Adresse (Korff, Petersen og Consorter), og for at erklære, at Tilstanden her er meget god, og at de muske at beholde Embedsmændene. De skulle være blevne godt modtaget og faaet tilfredsstillende Besked.

15. Marts. Stempelpapirforvalter Andreas Christiansen er suspenderet ${ }^{1}$ ). Maa stille Kaution (ved W. og Peter Schmidt for til November at betale $3000 \mathrm{Rdl}$. ?)

16. I Handelsforeningen bliver der gjort et Forsøg paa at styrte Direktionen og Udvalget. Omtrent 60 nye Medlemmer melde sig ind, for at Slesvigholstenerne kunne faae Majoritet. Forsøget mislykkes, fordi Optagelsen af de 60, uden den forskriftsmæssige Forundersøgelse, bliver afslaaet.

17. Der passerer 10-12 Embedsmænd fra Jylland herigjennem som Fanger: Amtmændene BilleBrahe, 2 Dahl'er og Nielsen ${ }^{2}$ ), Kammerherre Jessen, Borgmester Monrad ${ }^{3}$ ).

18. Marts. Schack ${ }^{4}$ ) fra Tønder er her. Andreas Christiansen har faaet sin Afsked. Bauditz ${ }^{5}$ ) er saaret,

1) Sidste Indehaver af det bekendte flenshorgske Handelshus; efter dettes Opløsning i Midten af 50erne Stempelpapirforvalter for Hertugdømmerne. Amter.

2) Amtmændene over Skanderborg, Aarhus, Vejle og Ribe

3) Henholdsvis Borgmestre i Horsens og Kolding.

) Grev Brockenhuus-Schack, Amtmand i Tonder.

3) Major B., Andr. Christiansens Svoger, haardt saaret ved Ragebøl 17. Marts, død 30. April i Flensborg. 
kommer i Morgen. Der synes at have været en større Kamp ved Dybbøl, synes gunstig for os. Wedell boer hos os; Middag d. 17 med Christiansens, Moltkes og Moder hos os.

19. Wedell og Schack med Koch ${ }^{1}$ ) og Moltke spise hos os. Wedell skal erklære sig angaaende de af ham ved Centralkassen i Sønderborg deponerede Amtspenge. Afgiver Erklæringen. Magistraten faar Paabud om Undersøgelse imod Christiansen paa Grund af Kassemangel. Christiansen har d. 6te Februar givet en Sum, circa 3000 Rdl. til Kranold ${ }^{2}$ ) (uden Kvittering!), og har undladt at opføre en Sum, circa 500 Rdl., som d. 7de pr. Post er indgaaet fra Tønder, i sine Bøger.

General von Raven ${ }^{3}$ ) bliver indkvarteret hos os for en Nat. Er en net Mand, meget høflig.

20. Marts. Bauditz ankommer saaret, bliver lagt paa Johanniter-Hospitalet. Mange Saarede. Preusserne synes at have lidt meget. Idag skal Kampen igen være i Gang, som der siges siden i Nat Kl. 3.

Min Kones Fætter Ræder ${ }^{4}$ ) er igaar arresteret, fordi han uden Legitimationspapirer seent om Aftenen er gaaet tilfods fra Flensborg til Lyksborg og ifølge Rapporten har svaret uforskammet og ikke villet tale tysk. Commandanten mener, at han snarest vil blive frigiven.

1) Appellationsretsraad i Flensborg.

2) Den daværende Generaldecisor for det slesvigske Regnskabsvæsen, død som Amtsforvalter i Odense 1889.

3) Preussisk Ingeniørgeneral, faldt 18. April.

4) Ministeriel Embedsmand og historisk Forfatter. Før Krigen Amtsekretmr i Tønder. 
Wedells afreise idag. Schack ogsaa. Mange Fanger gaa med Jernbanen.

22. Marts. Kongen af Preussens Fødselsdag bliver slet ikke høitideligholdt her. Om Aftenen kun nogle Illuminationer i Angelbogade - ogsaa hos Pastor Dame. Gratulation hos Zedlitz! En saakaldet Flensborger Deputation: Fedder Momsen, Nane Jürgensen, Henningsen, Funcke, Petersen ved Norretorv, PetersenKorff. - Om Eftermiddagen kommer Wrangel. Jeg gaar efter Befaling til ham. Han indbyder mig til Middag (!), men jeg siger nej; det er en Diner til Højtideligholdelsen af Fodselsdagen.

24. Marts. Intet er at se i Dagens Anledning, kun et stort sort-rødt-gult Flag hos Hertzbruch. Det er dog et stærkt Stykke! Hertzbruch sender et Prøveblad af "Norddeutsche Zeitung“. Til mig er Intet bleven meddelt derom :

25. Marts. Wrangel afslaar at betale Omkostninger for de danske Saarede. Han har sagt til mig den 7. Februar: „De skal sørge for do danske Saarede, som om det var mine Børn; de skulle have Alt, lad Rasmussen anskaffe Alt -- jeg betaler alting!"

Om Aftenen besøger min gamle Ven fra Heidelberg Grev Schmiesing-Kerssenbrock mig. Han er her med Malteserne, har de fromme Brødre og Søstre (100) her og andre Steder under sin Opsigt. Det er mig en stor Glæde at gjense den retskafne Mand.

August Ingwersen indgiver en Ansøgning til Civilkummissærerne, om at Trangslaanet for Rickertsens Børn maa blive bevilliget og godtgjort. Det er dog det stiveste, jeg har hørt! 
26. Marts. Jeg besøger Grev Schmiesing, træffer dér Revertera og Grev Thun.

Georg Ræder bliver losladt, efterat der or optaget en Protokol med den Befaling, at han øieblikkelig skal afreise med Jernbanen. - Bertouch er her. - Besøgt Bauditz; han ser elendig ud.

31. Marts. Schmiesing spiser hos os.

Louth fortæller mig, at to Mænd havde været hos ham, som havde sagt, at, de vare sendt af Flensborgs Borgere for at opfordre ham til endelig nu at heise det slesvig-holstenske Flag (idag er det Baron Zedlitz's Fødselsdag). Da han spurgte dem, hvem de vare, svarede de: Grev Baudissin (!) og Lærer Hansen. Han har forhandlet temmelig længe med dem og tilslut afvist dem.

1. April. Jeg reiser med den preussiske MilitærJernbane-Kommission og de preussiske Postembedsmænd til Rødekro. Jeg opnaar, at Banen ikke gaar lige nordpaa, men anløber Flensborg.

2. April. Alt tyder paa, at Hovedangrebet tilligemed Overgang til Als med Baade og Flaader skal finde Sted i Nat. Kl. 4 inat toge Officererne fra Hovedkvarteret derhen. Ogsaa Zedlitz og endogsaa Harnekaptain Hansen. Naar Dybbøl er taget, skal her feires en stor Fest. Der skal ringes med alle Kirkeklokker. Det er en Dag og Nat fuld af Bekymring, skjøndt jeg dog er ved godt Mod. Man vil nok passe paa i Dybbol og paa Als.

3. April. Hver Time, der gaar, bestyrker Formodningen om, at Dybbøl ikke er taget. Skudt og brændt blev der hele Natten. Kl. 4 reiste man herfra. - 
Endelig Kl. 11 kom de Første tilbage! Ingen Jubel, - falgelig er Alt gaaet godt. Mange Rygter, men det Ene er sikkert, at, som Kronprindsen af Preussen i største Vrede har sagt til Madam Rasch ved sin Hjemkomst, "Alt er mislykket", og Preusserne have lidt store Tab. Byen er stille og som uddod, der synes at herske Nedslagenhed. Wrangel havde sagt, at hans Folk kunde more sig idag, han kom forst sent om Aftenen tilbage - han vilde spise til Middag i Sonderborg - og nu kom han Kl. 11. Formiddag! Zedlitz har virkelig været med for strax at tage Als i Besiddelse; nu er han ogsaa kommet tilbage. Det er den forste gode Dag i 8 Uger, men nu længes vi efter bestemte Efterretninger! Folk tier forfærdeligt, der er Intet at erfare.

Plättner fortæller, at Preusserne her i Lazaretterne lægge de afdøde danske Soldater aldeles nogne $\mathbf{i}$ Kisterne. Preusserne iklæde de en Skjorte - Preusserne spare!

Louth modtager Betalingen for de preussiske Troppetransporter paa Jernbanen af den slesvigske Centralkasse!

4.-9. April. Bestandig Beskydning af Dybbøl. Massevis af Rygter. Haab og Frygt!

9. April. Kommissærerne slutte Kontrakt med Louth angaaende Driften af den nordlesvigskse Jernbane. De garantere ham 5 Rdl. pr. Vogn-Mil og 9000 Rdl. for Anlægsomkostningerne. Alt af den slesvigske Centralkasse. Jeg har sagt til Louth, at det slet ikke kan gaa an, og har sagt til Laffler, at det er 
en Kontribution paa Landet, - - det hjælper vel Altsammen intet!

10. April. Besigtiget den nordslesvigske Bane. Ifølge Preussernes Udsagn skal der idag skydes 100 Skud af enhrer af de 80 Kanoner paa Dybbøl. Vi høre den hele Dag Kanonaden. Til imorgen er der bestilt Vogn for Hovedkvarteret til Dybbøl.

15. April. Funcke, Bune, Callsen gaa igjen rundt for at samle Underskrifter angaaende min Afsættelse.

17. April. Major Funcke, Kommandanten, siger Farvel.

18. April. Storm paa Dybbøl. Begynder Kl. 10. Angst! Vi gaa Kl. 3 til de Danskes Høi. Paa Tilbageveien møder Efterretningen os allevegne. - Denne Følelse er ikke til at beskrive. Egentlig Jubel viser sig ikke, derfor har man altid endnn Haab om, at Sagen ikke staar saa aldeles slet. Mange slemme, ogsaa nogle gode Rygter komme. Henad Aftenen ankomme fangne Officerer, forst 13, saa flere, man siger 30-40. De blive indkvarteret i Borgerforeningen. Der bliver rekvireret Kvarter for 3-4000 Fanger. Det bliver anvist paa Lofterne i Mariekirken og den danske Kirke. Der bliver rekvireret mange Lazaretter. Alle Læger ere derude. De mange Fanger komme, blive ndmærket forpleiet af Flensborgerne. Fra alle Sider kommer Hjælp. Om Aftenen illuminere Enkelte, dog ikke Mange. Hele Natten ankomme Fangerne; Rygter om Saarede og Faldne!

19. April. Henimod Middag komme bestandig flere Saarede og Efterretning om de Faldne. 
Schau ${ }^{1}$ ) er bragt, haardt saaret. Han siger, at Sigismund ${ }^{2}$ ) er haardt saaret; dette stadfæester sig mere og mere. Kl. 3 gaar jeg til Schau; det er næsten sikkert, at Sigismund er dod! du Plat er falden! Sorgen bliver bestandig større, og saa de jublende Preussere og de glade Slesvig-Holstenere! Skrækkeligt! Kl. 5 siger Schmiesing til mig, at Sigismund milaske endnu lever og er i Nybøl. Jeg kjører til Graasten - erfarer der hans Død! Der skal være faldet 90 danske og over 60 preussiske Officerer. Megen Deltagelse angaaende Sigismund, ogsaa hos Preusserne. Imorgen lader jeg Liget hente. Søster Lutte rciser imorgen til Kjøbenhavn.

20. April. Flere og flere Saarede komme. Jeg sender Vogn til Nybøl. Telegram at Franciskia ${ }^{3}$ ) kommer. Fangerne blive sendt bort pr. Jernbane, Officererne allerede igaar. Forberedelser til Modtagelsen af Sigismunds Lig; hans stakkels Kone! Stakkels Moder og vi Alle!

Vognen kommer tilbage uden Liget!

I Overensstemmelse med en igaar af Herr Oberst von Blumenthal given Tilladelse beder den undertegnede Overpræsident, Kammerherre von Rosen i Flensborg, om velvilligst Cdlevering af den faldne Major von Rosens Lig, tilligemed hans eventuelle Effekter, til Transport hertil.-

Flensborg, d. 20. April 1864

C. v. Rosen

1) Stabschef ved 2. Armédivision.

2) Overpræsidentens Broder. Se Side 272.

3). Major Rosens Hustru. 
Svar tilbage til Hr. Præsident v. Rosen, Flensborg.

Major v. Rosens Lig er allerede igaar d. 19de paa særlig Befaling af den kommanderende General, tilligemed de fundne Effekter, bleven transporteret til Sønderborg og der modtaget af danske Officerer. De sidste Ønsker har jeg skriftlig og telegrafisk ladet afsende til Kammerjunker v. Rosen i Kjøbenhavn.

Johanniter-Hospitalet i Nybøl.

\section{Prinz Reuss.}

21. April. Kongen af Preussen kommer. Ifølge en Skrivelse fra Zedlitz gaar jeg til Banegaarden i civil Paaklædning med Ordener. Jeg forholder mig helt stille paa Perronen imellem Officerer, Zedlitz, Revertera etc. Man er meget hoflig imod mig. Alle condolere - mange som jeg ikke kjender. Zedlitz siger, at han havde fundet det rigtigt at meddele mig Kongen af Preussens Ankomst, og takkede mig, fordi jeg var kommen. Jeg svarede, at jeg havde holdt det for min Pligt, men bad forresten om, at det maatte tillades mig at holde mig aldeles i Baggrunden. Zedlitz bukker og siger, at han dog vilde meddele mig, at Kongen af Preussen selvfølgelig, og som det ligger i Forholdene, paa ingen Maade vil træde i Forbindelse med Befolkningen, da hans Besøg kun gjaldt Arméen, som Kongen vilde hilse paa. (Jeg fik det Indtryk, at Zedlitz ønskede at retfærdiggjøre Kongens Besøg.) Paa Perronen vare foruden mig, der holdt mig helt tilbage, kun Officerer. I 2den Klasses Venteværelse var en Mængde unge Piger. I 3. Klasses Venteværelse Officerer og nogle Deputationer fra andre Byer $0 \mathrm{~g}$ Amter; jeg ved ikke hvilke, da jeg slet ikke var derinde. Flensborgske Autoriteter var der slet ikke. Uden- 
for Banegaarden stod kun faa Folk og mange Soldater. Opad Raadhusgaden stod der helt fuldt af Soldater og var opstillet en Hoben Flensborgere med sort rødt gyldent Flag, (saa vidt jeg kunde se). Det skal have været Euterpe. Jeg saa kun Petersen og von Barm, som stode helt overst, da jeg gik til Banegaarden. Da Toget kjørte ind foran Perronen, stod Kongen af Preussen ud af sin Vogn omfarnede og kyssede flere Prindser. Saa gik han langs Tropperne, som vare opstillede sydpaa ved Siden af Perronen, og derpaa ind i Værelset, livor de unge Damer vare opstillede. Dér skal Frøken Schwennsen have holdt en Tale til ham. Han kom snart ud igjen, gik derpaa igjennem 3. Klasses Venteværelse og tilfods til Rasch's Hotel. Alt var temmelig stille - faa Mennesker, kun Soldaternes Hurra. Jeg gik hjem ad Gaardender, jeg kunde ikke længere holde det ud. Dette var første Gang, at Argrelse og Sorg fik Overmagt over mig.

Franciska reiser igen Kl. 3 sammen med Moder og Junas ${ }^{1}$ ) til Kjøbenharn. Mange Saarede afgaa med med samme Tog! Alt er saa sorgeligt!

Kongen af Preussen spiser Frokost hos Kronprindsen i Rasch's Hotel, - kjører saa gennem Byen nordpaa. Der er meget stille paa Gaderne, næsten ingen Mennesker, i hele Norden kun enkelte, 3-4 Flag. Stemningen her er let at forstaa, og aldrig vist tydeligere end idag. Kongen kommer forst tilbage imor-

1) En yngre Broder til Khr. Rosen; da ansat i det holstenske Ministerium, senere Landraad i Haderslev. 
gen, men alligevel bliver der idag befalet Illumination af "tyske Borgere i Flensborg “. Stoehr illuminerer i min Budstue, men bliver afvist med Eftertryk. Illnminationen er overordentlig sparsom, i hele Norden kun et Par Huse. Kl. 101/2 kommer Kjøbmand Hoeck, Bang og Biehl til mig og melde, at en Folkehob slaar Ruder ud. Jeg iler med dem til Kommandanten, som allerede er iseng, og forlanger Patruiller af ham, hvilket han lover. Forresten var allerede, dengang jeg kom tilbage fra Norden, hvor Kommandanten hor, Hoben jaget fra hinanden af Grev Stollberg. Der er ituslaaet temmelig mange Vinduesruder. Politimesteren har rolig siddet hos Rasch, men han bliver skjældt frygtelig ud af Stollberg. Der siges, at i Pobelhoben har været: Klock, Skipper Hansen, ogsaa Petersen og v. Barm og Callsen med deres Koner.

22. April. Kl. 6 om Aftenen kommer Kongen af Preussen tilbage. Om Aftenen illumineres der atter svagt. Kongen har slet ikke ladet sig se. I Gaderne er der meget stille. Om Aftenen blev Ruderne slaaet ud hos Klock, og Kaptain Hansen skal have faaet. mange Prygl.

22. April. Vi faa Indkvartering. Regjeringspræsident Kammerherre Henningsen (?) fra Gotha med en saaret Søn (Preusser). De spise med os, og vi tale meget oprigtigt. Jeg forklarer dem Alt efter bedste Overbevisning. Endogsaa disse (Sonnen er en Svigersøn af Major Schmidt, som er Adjudant hos Friedrick af Augustenborg) have opgivet Augustenborgeren; Sønnen erklærer Hertugen af Coburg-Gutha for en høist uafholdt confus Mand, sin egen Svigerfader dito. Saa- 
dan et Besøg er meget nyttigt; de toge Afsked med Tak for Modtagelsen, især fordi der var vist dem saa megen Høflighed af en "Fjende“.

23. April. Kongen af Preussen besøger Lazaretterne, spiser til Middag hos Rasch og afreiser Kl. 3. Alt er stille, Ingen hilser, han maa være klar over Flenshorg. Ninister Roon kom med ham, ligesaa Fløjadjudant Manteuffel. Minister Bismarck kom ogsaa igaar Aftes. Kl. 3 begraver vi 34 Soldater, derimellem Officersaspirant Øst. Schau befinder sig slet.

Du Plats Lig er igaar, meget smukt bekrandset, bragt til Sonderborg.

Borgerdeputeret Jensen siges at være reist til London!

24. April. Schau er død inat. Liget bliver bragt til Kapellet; smuk Hoitidelighed. Hans Kone kom ikke idag.

Grev Stollberg er meget hoflig og imodekommende angaaende Schau's Lig. Ogsaa Schmiesing gjor sig al Umage for at hjælpe. Scharffenberg er ikke begravet ved Dybbøl.

Igaar Aftes skal Funcke i "Euterpe" have forelest et Brev fra Zedlitz til ham, hrori der har staaet, at Flensborgs Magistrat længe har været ham (Zedlitz) en 'Torn i Øiet, men at han ikke kunde bevirke Magistratens Fjernelse, hvis der ikke blev foretaget ganske overordentlige Demonstrationer fra Borgernes Side.

Revertera vil ikke underskrive min Afskedigelse, -. det stadfæster sig altid ig.jen. Jeg hører fra Kontoret, at den ligger parat allerede underskreven af 
Zedlitz. - Bremer ${ }^{1}$ ) er her med Kone og alle sine Sager.

25. April. Atter nye Tropper komme Sydfra.

26. April. Majorinde Schau afreiser. Brev fra Johannsen ${ }^{2}$ ). Altsaa : Holde ud!

D. 13. Maj afskedigedes Overpræsident v. Rosen af Civilkommissærerne.

1) Medlem af den provisoriske Regering i 1848. Blev 13. Maj 1. Borgmester i Flensborg.

2) Den dav. Minister for Slestig. 